\title{
A Case Study of Modern Medical Practice and Islamic Complementary Therapy on a Patient with Over 2000 Embedded Nails
}

\author{
Nor Azian Ab Rahman ${ }^{1}$, Sagiran Sukardi ${ }^{2}$, Supyan Hussin ${ }^{1}$ \\ ${ }^{1}$ Institute of Malay World and Civilization, National University of Malaysia (UKM), Bangi, Malaysia \\ ${ }^{2}$ Faculty of Medicine, Muhammadiyah University Yogyakarta, Yogyakarta, Indonesia
}

\begin{tabular}{l} 
Article Info \\
\hline Article history: \\
Received Aug 24, 2015 \\
Revised Sep 27, 2015 \\
Accepted Oct 29, 2015 \\
\hline
\end{tabular}

\section{Keyword:}

Black magic

Holistic approach

Islamic complementary therapy

Mysterious medical illness

Jinn affliction disease

\begin{abstract}
In South East Asia, patients often resort to various forms of complementary therapy apart from utilizing mainstream modern medicine in Hospitals. Islamic-based complementary therapy employs various forms of biophysical, psychological, social, cultural, and spiritual interventional methods based on the prevailing belief and cultural system to provide a holistic Syariah compliant approach in patient management. The concept of diseases caused by sorcery and paranormal means using intermediaries like Jinn and evil spirits that have been in existence since time immemorial across religions, cultures and societies around the world. Currently, the practice of black magic and the belief in the paranormal still widely exist in the midst of modern civilization in this region. Modern medical practice has no definitive answer for a person with an unusual medical illness who is believed to have been afflicted by black magic because of its non-specific clinical presentation and non-response to conventional management paradigm which defies medical logic. In this paper, we describe a true case of a lady, who suffered from more than 2000 nails embedded inside her body for one and a half years. Upon admission to a hospital in Indonesia, she underwent a surgical procedure to remove all of the nails but to no avail; the nails re-appeared at other parts of her body. The surgical team later decided to conduct an Islamic complementary therapy on the patient, and subsequently, managed to extract all of the remaining nails without further bleeding. In conclusion, unusual or mysterious medical illness, sometimes referred to as idiopathic in etiology, not responding to conventional medical or surgical intervention, may potentially benefit from the use of Islamic complementary therapy.
\end{abstract}

Copyright () 2015 Institute of Advanced Engineering and Science. All rights reserved.

\section{Corresponding Author:}

Nor Azian Ab Rahman, Institute of Malay World And Civilization, National University of Malaysia, Bandar Baru Bangi, Selangor, Malaysia.

Email: azian_rahman@yahoo.com

\section{INTRODUCTION}

In South East Asia, patients often resort to various forms of complementary therapy apart from utilizing mainstream modern medicine in hospitals. Islamic-based complementary therapy employs various forms of bio-physical, psychological, social, cultural, and spiritual interventional methods based on the prevailing belief and cultural system to provide a holistic Syariah compliant approach in patient management. The concept of diseases caused by sorcery and paranormal means using intermediaries like Jinn and evil spirits that have been in existence since time immemorial across religions, cultures, and societies around the world, for example, Homer in Ancient Greece, the legendary Medea, and Witch of Endor in the Bible. Currently, the practice of black magic and the belief in the paranormal still widely exist in the midst of 
modern civilization in this region [1]. Modern medical practice has no definitive answer for a person with an unusual medical illness who is believed to have been afflicted by black magic because of its non-specific clinical presentation and non-response to conventional management paradigm which defies medical logic.

Black magic is defined as magic involving the supposed invocation of evil spirits for evil purposes (Oxford Dictionaries, 2015); a type of magic which is believed to use the power of the Devil in order to do evil (Oxford Advanced Learner Dictionary, 2015); black magic has traditionally been referred to the use of supernatural powers or magic for evil and selfish purposes [2]. Black magic is a paranormal practice that has been spreading in this region affecting the person's mind, brain and body and baffling the medical science. Diseases related to black magic cannot be diagnosed by the modern medicine medical equipment. Alternatively, the Islamic complementary therapy is one of the popular methods that may complement the modern medical practice. The Islamic complementary therapy has been in practice since the beginning of the Islamic history.

Complementary medicine, in practice refers to a wide range of health interventions originating from different cultures across thousands of years of history (Scottish Office Department Of Health, Complementary Medicine and The National Health Services, London, November 1996). "Islamic Medical Practice" is the effort at seeking treatment for physical and spiritual ailments, conducted by a Muslim who is knowledgable and skilled in treatment methods using Quranic verses, Hadith, the practices of the pious and righteous scholars, and of the venerated religious teacher, and also skilled with the use of methods or materials permitted by the Islamic law [3]-[7].

One of the important elements of black magic is the use of Jinns as an intermediary between the black magic practicioner and the potential victims. Jinns are invisible creatures mentioned in the Quran, the Bible, the Veda and other religious scriptures [8],[9]. According to Muslim belief, Jinns are used in black magic, and can go into the human body through the blood vessels that can cause "afflictions" "illness", mentally, physically or spiritually [5],[7],[8]. The illness may appear with medical signs and symptoms but eventually the diagnosis becomes unusual or mysterious and may not be responding to conventional medical or surgical interventions. In such instances, Muslims in this region often seek Islamic Complementary Therapy to treat patients who are believed to have a jinn afflicted disease caused by black magic [4],[5],[6].

\section{RESEARCH METHOD}

This a case study of a patient who suffered from 2000 embedded nails in her body for 18 months. Miss S, 25 years of age, has been agoniziing from the continuous pain due to this unknown cause. Both of her legs were covered with wound and swelling. Some parts of her body were suffering from skin necrosis. During her first visit to Nur Hidayah Bantul Hospital Yogyakarta, Indonesia, as indicated by DrSagiranSukardi and the medical team spotted three nails and a golp of hair on her right leg, as illustrated in Figure 1; and two nails from her left calf. X-ray results showed that her body was full of foreign materials consisting of metal like nails, wire, and needles as illustrated in Figures 2-4. The patient was diagnosed as Corpus AlienumLogamRegioCruris Bilateral Multiple with Abces and grangrene. The surgeon decided to perform debridement surgery and Corpus Alienum extraction. The first surgery successfully removed 71 nails from the patient's body. The next day, another four nails came out from her body naturally. On the third day, the medical team took her for another x-ray and found 12 more nails in her body which wereremoved surgically.

There were a total of 118 foreign metal materials including nails removed during her stay at the hospital. She underwent repeated surgical procedures to remove all of the nails but to no avail; the nails reappeared on the other parts of her body. The surgical team later decided to conduct an Islamic Complementary therapy on the patient, and finally, managed to extract all of the remaining nails without further bleeding. It was recorded that allegedly 2028 nails, wire and needles came out from her body before she was treated at the hospital and another 60 nails, wire, and needles after she was discharged from hospital.

The patient also had spewed nails along $10 \mathrm{~cm}$ in transverse position from her mouth during the Islamic Complementary Therapy session.The therapy started early in the morning the very next day after her surgery, she felt chronic pain in her stomach and struggle through it. The severe pain goes up to her chest and continued up to the neck. This has caused her to feel choked and suffocated; while the practitioner kept on reciting Ruqyah (reading of verses from the Holy Quran) as part of the therapy, she vomited a $10 \mathrm{~cm}$ nail without causing any bleeding. The next day onwards, nails came out naturally from her body without any surgery as she continued with the therapy. The patient showed good progress, and was able to control the attacks from the black magic. The healing process continued until she recovered from her sickness. 


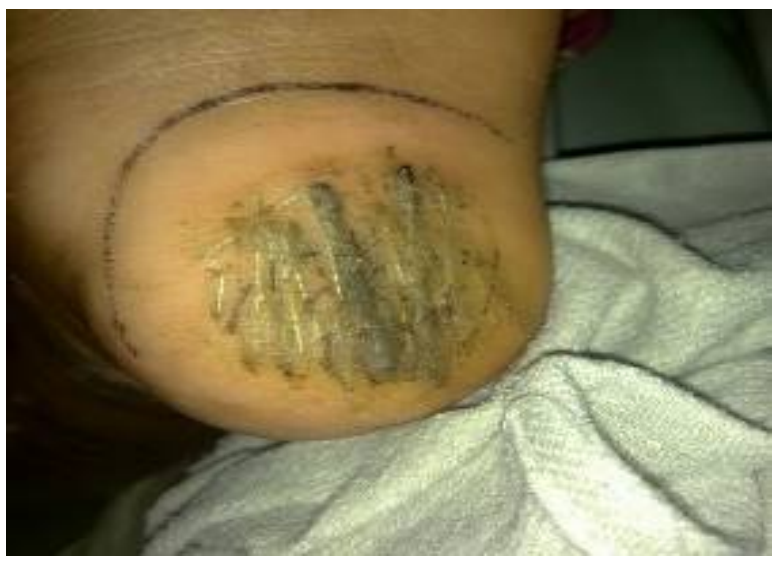

(Coutersy by DrSagiranSukardi)

Figure 1. Nails on right leg

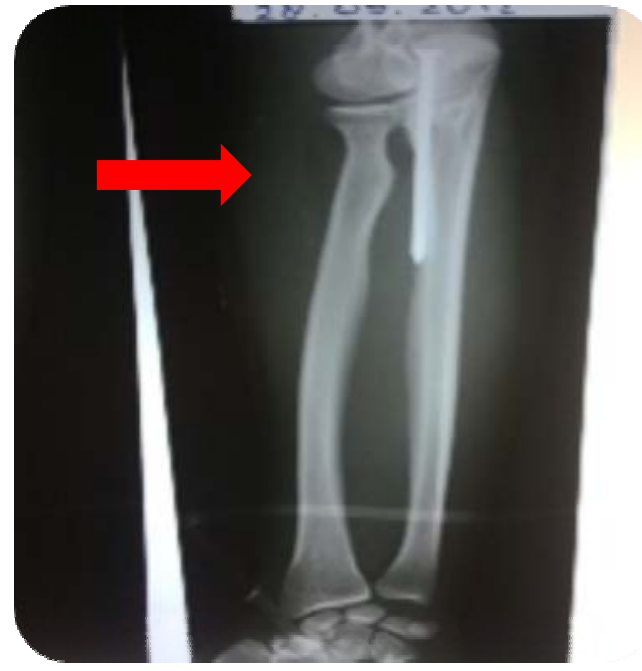

(Coutersy by DrSagiranSukardi)

Figure 3. Foreign objects (nails) in the lower right arm

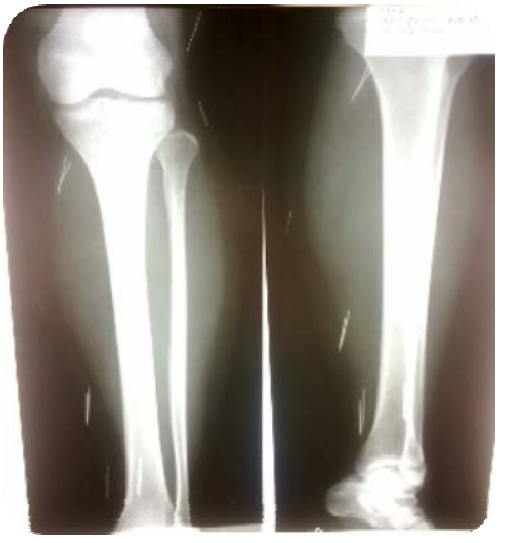

(Coutersy by DrSagiranSukardi)

Figure 2. Foreign objects (nails) on the left leg of the lower limb

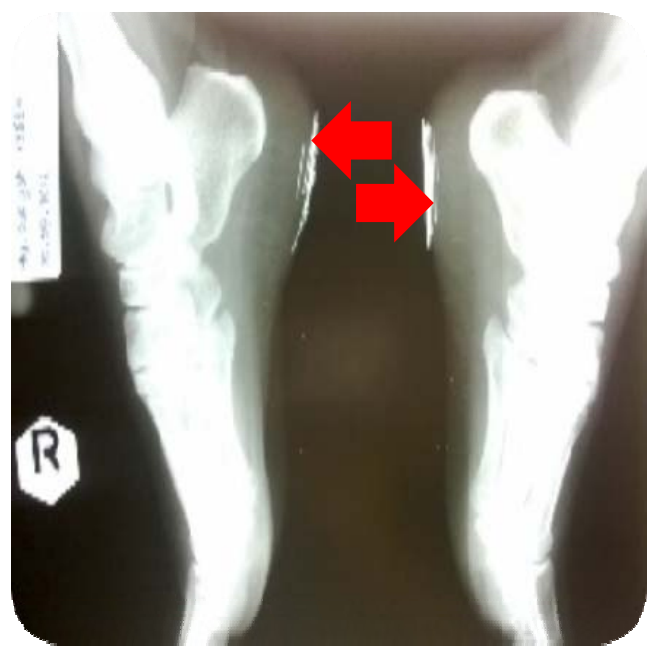

(Coutersy by DrSagiranSukardi)

Figure 4. Foreign objects (nails) on both heels

\section{DISCUSSION}

The practice of black magic is prevalent in modern Southeast Asia, and for decades this phenomenon has been perceived to have led to numerous mysterious medical cases within the community. Modern medical patient intervention for black magic cases may result in no definitive diagnosis in medical reports. Patient may suffer a continuous illness not responsive to treatment. The removal of black magic cannot be done by medical intervention, and this has been the underlying problem in patient management for jinn affliction illnesses. The lady patient was treated as a medical case at the initial stage and underwent multiple surgical procedures but despite the successful surgeries, nails reappear in her body mysteriously within 24 hours which defied medical logic. Similarly, a person suffering chronic pain in an area in the body 
but undiagnosed medically may perhaps be cased Jinn`s intervention through black magic. Or if a patient who has been treated with medical procedures but results in no response to conventional treatment could probably be suffering from the black magic.

The lady patient, experienced an unreasonable circumstances when she spitted a $10 \mathrm{~cm}$ nails which she never swallowed. The long metal objects in her stomach were removed without any surgery which is something that considered impossible in conventional medicine but it can be done through the Islamic Complementary Therapy method. The Islamic Complementary Therapy theories diagnose the condition occurs as caused by the evil spirits; a concept that conventional medicine difficult to prove the existence of supernatural from the medical perspective. This particular patient case, and most probably many other cases in this region, may be the answer to the collision point between faith and science in the medical field.

Apparently, medicine and surgical intervention were not successful enough to deal with the mysterious embedded nails in this lady as the nails keep on appearing in her body. This scenario is, indeed, a major indication of an illness caused by Jinn via black magic. Jinn, like the virus, enter the human body and goes into the blood vessels using black magic spells. There is no standard key distinguishing feature between medical illness and Jinn affliction illness as yet. Patients suspected with Jinn affliction illness can be assessed by the Islamic Complementary Therapy practitioners who usually could remove the Jinn, by God's will, using several treatment methods or theraphies. The healing process may require several visits, and the patients may exhibit several responses and symptoms during the treatment. The responses may differ from one patient to another, depending on the types and stage of the black magic. The use of medical equipments, clinical tests or lab tests as diagnostic tools are necessary at the beginning stage of diagnosis procedure, but is inappropriate in black magic cases, and perhaps there will be specific tools for diagnosis and assessment in the future. Further explanation on the theories of black magic in causing illnesses are required or it will remain questionable within the medical fraternity unless proven by scientific methodology.

\section{CONCLUSION}

This complementary medicine is nothing new now in the World Health Organization (WHO). Traditional Medicine Strategy 2002-2005 promotes the integration of Traditional and Complementary Medicine (TCM) into the National Healthcare system. This is in line with the prevailing belief among the Malay Archipelago that Jinnsis considered as a source that may have causedsome unknown illnesses. The case study of an Indonesian lady patient demonstrates the feasibility of integrating Islamic Complementary Therapy with modern medicine therapy in the hospital setting. However, further research needs to be carried out to clarify its role and mechanisms of action and whether cure is more than just a placebo effect. The methodology of Islamic Complementary Therapy that is being used needs to be scrutinized and regulated to be in the conformance with medical, religious, and ethical standards to safeguard public safety. Nevertheless, the well being of the patient and the illness recovery are the expected ouctcomes of any treatment, be it modern medicine or complementary medicine.

\section{ACKNOWLEDGEMENTS}

This paper is a small portion of the research on indigenous knowledge of healing, sponsored by a research grant, i.e. Long Term Research Grant Scheme (LRGS): Conceptualizing Local Knowledge: A Study of Sustainable Values in Local Wisdom and Indigenous Science (2012-2016), and Holographic Transdisciplinary Conservation 203/PTS/67270007. The X-ray graphic and the picture as well as the content of the case study have been furnished by DrSagiranSukardi. One important person who has been instrumental in this research is UstazFadlan Abu Yasir, a well known practitioner of Ruqyah Therapy in Indonesia.

\section{REFERENCES}

[1] Mohd Koharuddin b. Mohd Balwi, “Sains Perubatan Naturalistik Melayu: Satu Kajian Awal”, Jurnal Kemanusiaan UTM, vol. 2, pp. 34-41, 2010.

[2] Melton, J., "Black Magic”, Encyclopedia of Occultism \& Parapsychology, vol. 1: A-L (Fifth ed.), Gale Research Inc., 2011.

[3] Ministry of Health Malaysia, “Traditional and Complementary Medicine Programme in Malaysia”, Kuala Lumpur, Ministry of Health, 2011.

[4] Engku Ansaruddin Agus, Mohd Azlee A. Mutalib MD, "Perangi Sihir”, Kuala Lumpur, PTS Millennia SdnBhd, 2012.

[5] Haron Din, "Rawatan Penyakit Akibat Sihir”, Bangi, Persatuan Kebajikan dan Pengubatan Islam Malaysia (Darussyifa) \& Koperasi Darussyifa’ Berhad, 2012.

[6] Ismail Kamus, “Jin Hakikat \& Pengubatan” Kuala Lumpur, Telaga Biru Sdn Bhd, 2006. 
[7] Sharifah Norshah Bani Syed Bidin, "Ayat-ayat al-Quran Sebagai Terapi Kerasukan Jin: Analisis Dari Ayat-ayat Ruqyah Sya’riyyah”, Center Of Quranic Research International Journal, pp. 107-138, 2011.

[8] Nurdeen Duraseh, "Health And Medicine In The Islamic Tradition Based on the Book of Medicine (Kitab ALTibb) Of Sahih Al-Bukhari”, JISHIM, 2006.

[9] Wahid Abdussalam Bali, "Man’s Protection against Jinn and Satan”, Dar Al-Kotob Al-Ilmiyah, Beirut-Lebanon, 2006.

\section{BIOGRAPHIES OF AUTHORS}

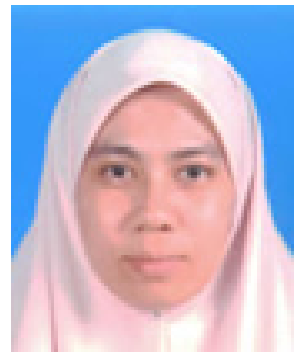

Ms. Nor Azian Ab Rahman

- BA Accounting, Western Michigan University, USA

- MSc Information Technology, UPM, Malaysia

- PhD candidate, National University of Malaysia

Assistant Secretary, Federation of Islamic Medical Treatment Practitioners Malaysia

Islamic Complementary Parcticioner, DarulSyifa, Bangi Malaysia

Graduate research assistant, Holographic Transdisciplinary Conservation

203/PTS/67270007, UKM LRGS/TD/2012/USM-UKM/KT/03

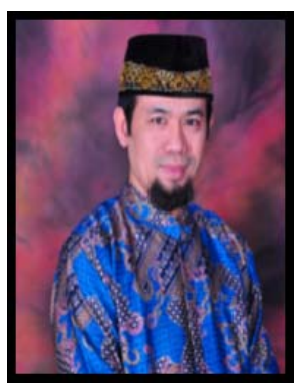

Sagiran Sukardi, MD, M.Sc., Ph.D, FINACS, FICS.

Lecturer in the Faculty of Medicine, UMY

Surgeon Specialist

Pendidikan Pengobatan Tradisional Akupuntur, Akupreser, dan Jamu Tradisional dan Praktek, Diklusepora, Yogyakarta, 2004.

Work experiences: Doctor PTT atPuskesmasNgampilan Yogyakarta, Medical Doctor RSU PKU Muhammadiyah Yogyakarta, Lecturer Anatomi and Surgery Department FK, UMY Leadership positions: Chairman YayasanNurHidayah, Assistant Dean I FK UMY, Director BP-RB At-Turots Al-Islamy, Assistant Dean I FK UMY, Secreatary Surgery Department FK UMY, Surgeon Team RSU PKU Muhammadiyah, Yogyakarta dan RS NurHidayahBantul, Head of Surgery Department FK Universitas, Muhammadiyah Yogyakarta

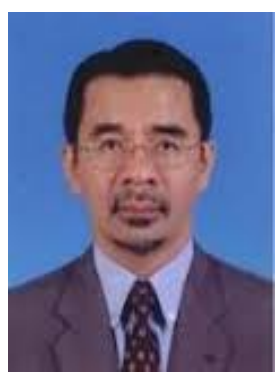

Supyan Hussin, Ph.D (Education) University of Illinois

Associate Professor, School of Language Studies and Linguistics, Faculty of Social

Sciences and Humanities, UniversitiKebangsaan Malaysia,

Deputy Director at the Center for Teaching and Learning Technologies, UKM.

Leadership position: Deputy Dean of the Faculty of Language Studies, the Head of ECommunity Research Center, and a Senior Fellow at the Institute of the Malay World and Civilization. UniversitiKebangsaan Malaysia. He is now a Deputy Chairman of the Malaysia Mobile Learning Association.

Head of Project 3 Holographic Transdisciplinary Conservation 203/PTS/67270007 and LRGS/TD/2012/USM-UKM/KT/03 